\section{BIRD TALK}

By Ona F. Lick, Davidson

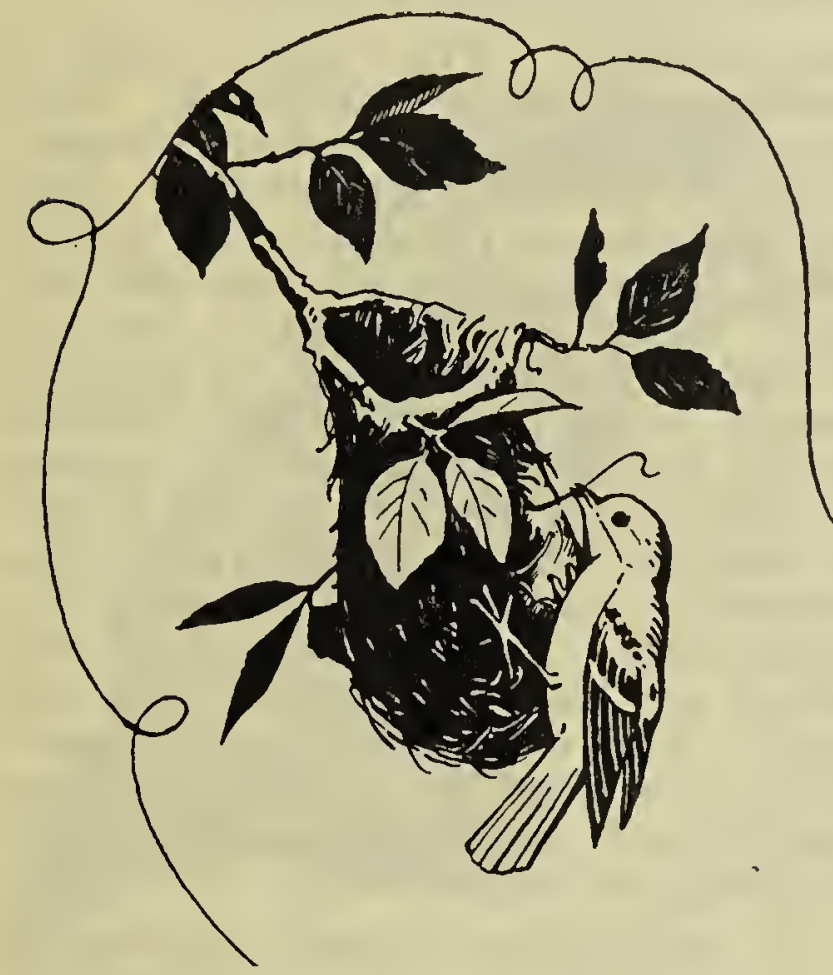

66 YOU SHOULDN'T do that." 1 That's what I imagined I heard him say to her, as I watched the pair from my kitchen window. "Why didn't you take four, or even five, when you could get them for nothing?" he continued. "Well," she retorted, "three were quite enough for me to carry. Why didn't you come and carry some yourself, instead of just flitting by, criticizing? Besides, others were in the line-up, ready to grab what I couldn't carry."

It was this way. I had seen a female Baltimore Oriole pulling and tugging at a string, which the wind had wound too tightly for removal, around the barbs of a wire fence, fifteen feet from my kitchen window. She jerked it. She jumped into the air with it in her beak pulling this way and that. She clung to the fence upside down still tugging in vain.

Realizing the housing shortage and the difficulty in obtaining building materials these days, I decided to help Mrs. B. Oriole build her happy little home; and so I strung a dozen or so bits of cord along the wire fence. No sooner was I back in the kitchen than the lady appeared and made off with one piece of string trailing behind her. Soon she reappeared, taking away three bits in her mouth. I was kept busy refilling the wire with bits of string; and I began to suspect that a second female had discovered easy building materials.. Several times a male flew by. At one point in the narrative, Mrs. Oriole sat on the fence awaiting her turn, while Mrs. Kingbird pushed her way in and seized two strings, while the barn swallows lined up to watch the competition.

The colors of the orioles enticed me-the dull orange breast and smooth brown back of the female, and the rich orange breast and shiny black back of the male. It was a picture of springtime in Saskatchewan I shall not forget, with the pink and purple honeysuckle and lilac in the background.

Dear me! I realize the expense of building a home. I must mark "One ball of string" on my shopping list.

\section{Dancing Ground}

By Cliff Shaw, Yorkton

A NYNE who has unexpectedly found a sharp-tailed grouse dancing ground will realize the treat we experienced May 14.

It was about seven o'clock in the evening and we had been driving along the country roads admiring the new leaves of the poplars and occasionally catching sight of small migrants as they flitted hurriedly across the road into the bushes.

As we approached a marshy area one mile east of Chrysler siding, approximately six miles southeast of Yorkton, four grouse flushed from a prairie knoll 75 yards back from a slough. We noticed several other grouse just inside the fence line so we stopped to watch them, separated only by the width of the ditch.

After a cursory glance the birds paid no further attention to the car with the exception of one bird who had flown back in and who remained watching us about 100 feet from the main covey. We did not have long to wait before becoming aware we were about to witness a spring courting dance.

What first caught our attention was one bird who began strutting around in a circle with wings spread, his head almost touching the ground and his tail held high. Four others squatted facing each other 10 feet apart as though undecided as to their next move. After what seemed to (Continued on page 19) 